\title{
Editorial
}

Editorial

\section{A CPLP e o desenvolvimento económico em Português}

\author{
CPLP and the economic development in Portuguese
}

\author{
Diretor da $\mathrm{e}^{3}$, Eduardo Leite ${ }^{1}$ \\ ${ }^{1}$ E-mail:diretor@revistae3.com \\ Instituto Superior de administração e Línguas \\ da Madeira (ISAL)
}

As explorações marítimas portuguesas difundiram, desde o século $\mathrm{XV}$, a língua portuguesa pelo mundo, dando origem a um valioso património sociocultural e linguístico que se mantém na atualidade. Em 1983, aquando de uma visita oficial a Cabo Verde, o então ministro dos Negócios Estrangeiros de Portugal, Jaime Gama, apresentou uma visão para capitalizar a herança dos nossos antepassados, referindo no seu discurso, entre outros aspetos, o seguinte:

O processo mais adequado para tornar consistente e descentralizar o diálogo tricontinental dos sete países de língua portuguesa espalhados por África, Europa e América seria realizar cimeiras rotativas bienais de Chefes de Estado ou Governo, promover encontros anuais de Ministros de Negócios Estrangeiros, efetivar consultas políticas frequentes entre diretores políticos $e$ encontros regulares de representantes na ONU ou em outras organizações internacionais, bem como avançar com a constituição de um grupo de língua portuguesa no seio da União Interparlamentar.

Já no final da década de 1980, início de 1990, o então Embaixador do Brasil em Lisboa, José Aparecido de Oliveira, deu um contributo importante na concretização dessa visão, mobilizando os seus conterrâneos, e não só, para a formação de uma comunidade dos países de língua portuguesa. Mais concretamente em novembro de 1989, a convite do Presidente brasileiro José Sarney foi promovido, em São Luís do Maranhão, um primeiro encontro dos Chefes de Estado e de Governo dos países de Língua Portuguesa, tendo estado presente: Angola, Brasil, Cabo Verde, Guiné-Bissau, Moçambique, Portugal e São Tomé e Príncipe. Neste encontro, deliberou-se criar 
o Instituto Internacional da Língua Portuguesa (IILP), tendo em vista a promoção e difusão do idioma comum a toda a Comunidade.

Posteriormente, num segundo encontro em Brasília, em fevereiro de 1994, os ministros dos Negócios Estrangeiros e das Relações Exteriores desses países, acordaram sensibilizar os respetivos Governos, para a realização de uma Cimeira de Chefes de Estado e de Governo, de forma a legitimarem a constituição da Comunidade dos Países de Língua Portuguesa (CPLP) ${ }^{1}$.

Desde então, beneficiando de uma matriz cultural e linguística comum, a CPLP tem vindo gradualmente a traduzir-se num espaço privilegiado de cooperação transnacional e transcontinental, garantindo-nos o efeito de escala e aumentando a nossa competitividade no quadro da globalização mundial. No entanto, a realidade dos mercados que compõem a CPLP é ainda desconhecida de muitos agentes económicos, perdendo-se recorrentemente oportunidades de cooperação económica e de negócios.

Na Conferência Internacional “A CPLP: Novos Desafios e Oportunidades”, a secretária executiva da CPLP, Maria do Carmo Silveira, corroborou dessa opinião ao referir a necessidade de aprofundar a cooperação entre os Estados-Membros, desenvolvendo melhores condições empreendedoras para a realização de futuros negócios ${ }^{2}$. Em outubro de 2017, realizou-se uma conferência económica em Maputo ${ }^{3}$, onde foram discutidos os factores de cooperação da Comunidade. Compareceram mais de 80 líderes lusófonos no Fórum Económico sobre Cidades Sustentáveis ${ }^{4}$.

É neste âmbito que a Ciência e o conhecimento têm um papel fundamental. Com efeito, a Ciência (do latim scientia, traduzido por "conhecimento") refere-se a

\footnotetext{
${ }^{1}$ Mais informações disponíveis no site oficial da CPLP: www.cplp.org.

${ }^{2}$ Conferir o artigo "Maior cooperação económica é um dos desafios futuros da CPLP", in Observador, 22 de fevereiro de 2017. Disponível em http://observador.pt/2017/02/22/maior-cooperacao-economica-e-umdos-desafios-futuros-da-cplp/.

${ }^{3}$ Ver o artigo "Confederação Empresarial da CPLP organiza conferência económica em Maputo em outubro", in Diário de Notícias, 21 de junho de 2017. Disponível em https://www.dn.pt/lusa/interior/confederacao-empresarial-da-cplp-organiza-conferencia-economica-emmaputo-em-outubro-8580799.html.

${ }^{4}$ Conferir o artigo "Mais de 80 responsáveis lusófonos em fórum económico em outubro em Macau", in Observador, 25 de setembro de 2017.Disponível em http://observador.pt/2017/09/25/mais-de-80responsaveis-lusofonos-em-forum-economico-em-outubro-em-macau/.
} 


\section{pontěditora}

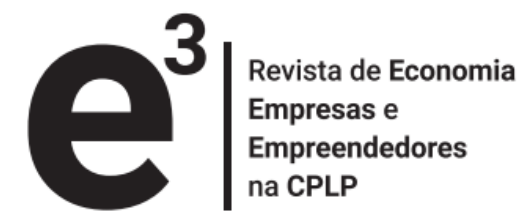

qualquer conhecimento ou prática sistemática. Por outras palavras, a Ciência é o esforço para descobrir e aumentar o conhecimento humano, questionando como tudo funciona.

Neste sentido, só através de ações práticas de investigação ou estudos racionais dos mercados da CPLP, direcionados à descoberta de oportunidades concretas, podemos ambicionar cumprir a visão da CPLP. Na realidade, a Ciência é o único processo de avaliar corretamente o conhecimento empírico. A Ciência dá origem a um corpo sistematizado e cronologicamente organizado de conhecimento, no qual teremos a verdadeira noção dos paradigmas válidos para estes mercados. Da mesma forma, teremos, também, a metodologia e a noção dos recursos necessários, para o sucesso do desenvolvimento de negócios nos países da CPLP e, destes, com o resto do mundo.

Assim, como aparecimento da revista $\mathbf{e}^{\mathbf{3}}$,em 2014, pretendeu-se integrar, desde logo, a corrente de apoio à concretização da visão para a CPLP através do conhecimento e da Ciência em Português. A publicação do V3N2 da $\mathbf{e}^{\mathbf{3}}$ assinala três anos de existência, os quais se caracterizam pelo trabalho e dedicação, cujo crédito gostaria de estender aos meus colegas dos corpos editoriais, autores e, claro, aos nossos leitores. Não poderia deixar de agradecer a todos por continuarem a fazer parte do nosso crescimento.

Aproveito, ainda, para referir que, com a integração da $\mathbf{e}^{\mathbf{3}}$ na startup Ponteditora e o lançamento de novas publicações, vou assumir a responsabilidade de Editor-chefe da RAF - Revista Académica de Futebol, passando a liderança da $\mathbf{e}^{3}$ à colega Prof. Doutora Ana Maria Alves Bandeira, a quem desejo muito sucesso e auguro grandes realizações, face ao seu percurso de dedicação e rigor. Por último, gostaria de deixar um agradecimento especial à colega Prof. Doutora Amélia Ferreira-da-Silva, por sempre ter acreditado e apoiado, tanto a ideia da revista, em 2014, como a sua materialização, traduzido em submissões e revisões constantes, até ao presente.

Muito obrigado! Votos de boa leitura.

O trabalho $\mathbf{e}^{3}$ - Revista de Economia, Empresas e Empreendedores na CPLP está licenciado com uma Licença Creative Commons - Atribuição-NãoComercial-Compartilhalgual 4.0 Internacional. 